OPEN ACCESS

Citation: V. Memoli (2020) The effect of the media in times of political distrust: the case of European countries. Quaderni dell'Osservatorio elettorale - Italian Journal of Electoral Studies 83(1): 59-72. doi: 10.36253/qoe-9532

Received: January 16, 2020

Accepted: April 04, 2020

Published: July 28, 2020

Copyright: (c) 2020 V. Memoli. This is an open access, peer-reviewed article published by Firenze University Press (http://www.fupress.com/qoe) and distributed under the terms of the Creative Commons Attribution License, which permits unrestricted use, distribution, and reproduction in any medium, provided the original author and source are credited.

Data Availability Statement: All relevant data are within the paper and its Supporting Information files.

Competing Interests: The Author(s) declare(s) no conflict of interest.

\section{The effect of the media in times of political distrust: the case of European countries}

\author{
Vincenzo Memoli \\ Department of Political and social sciences, University of Catania, Italy \\ E-mail:memoli@unict.it
}

\begin{abstract}
No study has yet explored the effect of all communication tools on political trust. Instead, studies on the media and their relationship with trust in political institutions have tended to focus on just a few types and have yielded contradictory results. This study aims to fill this gap, considering - on the one hand - television, the press and radio, and - on the other - the Internet and online social networks. Given that forms of media inevitably suffer from political choice as well as the political system, we analyse the effect of the media on public political trust. Based on pool data gathered by Eurobarometers (2014-2017) and multi-level regression techniques, it is possible to state that, of the various forms of media, the press and the Internet have a very significant effect on public political trust, as does media freedom.
\end{abstract}

Keywords. Media, Europe, political trust.

\section{INTRODUCTION}

In the last decades, the subject of political trust has attracted significant interest in the field of political science. Increased interest in social trust and its nexus with political trust, growing levels of disaffection with the political system on the part of citizens (Norris 1999, 2011) and fluctuations in political trust over time (Van Ham \& Thomassen, 2017) all continue to capture scholarly interest with regard to confidence in institutions.

How do the media affect public political trust? Debates about the role of the mass media in promoting political culture and affecting political support have generated opposing theories. On one side is the 'media malaise' thesis, which claims that the mass media affect citizens negatively, fostering political alienation by fuelling their cynicism (Mutz \& Reeves, 2005) and, on the other, is the 'mobilisation' approach, which claims that the mass media augment citizens' political interest, learning, efficacy and participation (Norris, 1999). The theoretical debate between these perspectives has rendered the relationship between the media and democracy highly controversial.

Since the 1990s, the power of the media in democracies has been widely acknowledged (Manin, 1995) and its effects are evident. The media comprise a set of institutions that play the role of the 'civic teacher' in demo- 
cratic societies (McComb, 2004), but some doubt persists as to their positive effect on democracy (Kellner, 2004). Despite a large number of studies on the subject, the effects of the media on the political system need further investigation, as suggested by Gunther and Mughan (2000) who, in examining the nexus between the media and democracy, highlight a paradoxical situation: in countries in transition the media play a crucial role in promoting the democratic process whereas, in mass democracies, they scarcely contribute to improving the quality of democracy. In other words, although the media represent a 'prerequisite for moulding the democratic quality of society' (Dahlgren, 2009, p. 108), they appear to have failed to consolidate democracies (Kleinnijenhuis, van Hoof \& Oegema, 2006) and, in the case of new media, have generated misguided mobs rather than an informed public (Viner, 2016).

In contrast to previous studies, this investigation distinguishes traditional media (television, radio and newspapers) from new media (Internet and online social networks) and considers the freedom of the press in order to analyse how media affect political trust in European countries. The decision to compare different forms of media stems from the fact that citizens have multiple news sources from which to choose and varied ways to share their political views. Only a comparison of all media can shed light on how the media are used to obtain political news, a process that shapes the trust the public then places in political institutions.

In the scientific debate around media and political trust, the role of the independence of the media is undoubtedly important: where the media are free, there is a greater pluralism of voices and values (Czepek, Hellwig \& Nowak, 2009), citizens are more satisfied with how democracy functions (Rodrìguez \& Zechmeister, 2018) and demonstrate greater political knowledge (Leeson, 2008). However, in the last twenty years, the freedom of the press seems to have atrophied (The Economist, 2018): the number of journalists who have been imprisoned or have suffered violence for their work has increased - even among northern European countries which have always been characterised by high levels ${ }^{1}$ of press freedom - and significant fluctuations are found in some countries of eastern and southern Europe, which have become or tend to be 'partially free' (Freedom of the Press, 2017). Given that control of public broadcasters by the political class could undermine the political

\footnotetext{
${ }^{1}$ A survey carried out in the spring of 2017 by the University of Tampere, Finland, and the Finnish Association for Investigative Journalism (TJY) found that one in four journalists had been the victim of verbal or physical violence triggered by articles on refugees, immigration and racism (Jouralisti, 2017).
}

support of citizens, illuminating the effect that media freedom has on political trust is a necessary step in defining the health of a democracy.

Using information gathered by Eurobarometer, this paper looks at levels of political trust between 2014 and 2017, a difficult period for European governments and their institutions, as the Great Recession, globalisation and peak of the migrant crisis prompted harsh criticism of governments. Thus, this study contributes to the literature by providing a better understanding of differences in levels of political trust between individual European Union (EU) member states as well as changes over time. Applying a fixed regression model, we find differences between media showing how they and the media system play an important role in political support.

\section{POLITICAL SUPPORT, CITIZENS AND POLITICAL INSTITUTIONS}

What do citizens really mean when they say they support democracy? Easton (1965) proposed a classification of political and institutional systems, combining three specific political spheres (political community, regime and authorities) with two types of political support (specific and widespread), but did not directly categorise political institutions or figures according to the type of support they enjoy. Subsequently, Norris (1999) expanded the original conceptualisation of political support, locating attitudes towards democratic regimes in the middle of a unidimensional continuum.

Adopting the institution-based notion of trust, political trust can be defined as the evaluation given of an entity (Van der Meer \& Hakhverdian, 2017), for example, a political party, government or parliament (Thomassen, Andeweg \& Van Ham, 2017) included in the core institutions of the state including branches of government (Norris, 2011). Political trust is useful in generating collective power (Gamson, 1968) and essential for the functioning of democracy (Hetherington, 1998) since it helps improve both the legitimacy and effectiveness of democratic regimes (Mishler \& Rose, 2001). Reflecting on the stability of political systems (Easton, 1965), political trust represents an essential component of civic culture (Almond \& Verba, 1963) and provides a reservoir of support when regime performance declines (Turper \& Aarts, 2017).

Political trust may be seen as an extension of generalised trust, assimilated through the process of socialisation and later transferred to the political system and its institutions (Levi \& Stoker, 2000). Others argue that the relationship between generalised trust and political trust 
is weak or even non-existent (Kaase, 1999) because they are 'different things with different causes' and 'largely independent of each other' (Newton, 2001, pp. 201-203). To explain political trust, one should use political variables (Newton, 2007).

Political trust is a multi-faceted concept: it has been conceptualised as a political orientation towards figures as well as institutions (Denters, Gabriel \& Torcal, 2007); political institutions have been defined in terms of being partisan or neutral (Rothstein \& Stolle, 2008), and others have added international classifications (André, 2014). Hooghe (2011) represents political trust as a one-dimensional concept, in which citizens' differing levels of trust in political institutions are synthesised in an index of political trust using factorial techniques or additive aggregation procedures (Kroknes, Jakobsen, \& Grønning, 2016). According to the established procedures used in the majority of studies on political trust, this study combined citizens' confidence in government, parliament and political parties into one single measure.

\section{MEDIA AND POLITICAL TRUST}

The media can be considered a determinant factor of political trust. The media and politics are two interconnected worlds, the first of which allows the public to know the policies defined by the second and activates discussion between social figures and interest groups. In mediating between the various social interests, the media are increasingly able to define citizens' attitudes towards and perceptions of the social and political issues within the national debate (Fryberg et al., 2012). The effects the media have on public opinion, and consequently on institutions, depend on the role they play within society and how they respond to citizens and institutions (Memoli \& Splendore, 2014).

It is well-known that familiarity with an object can create a more favourable assessment of it, provided that it is not connected to negative signals (Zajonc, 2001). One might, therefore, hypothetically expect that, when the media diffuse bad political news, levels of political trust should decline. However, it is not always so. In general, political news has a modest impact on support and the effect can be either positive or negative, depending on the medium (Van Aelst, 2017), the content and the coverage of the news (Gross, Aday \& Brewer, 2004) as well as on the citizens' ideological leaning (Brosius, Van Elsas \& de Vreese, 2019). Furthermore, in some countries, the decline of political trust 'would not necessarily be bad news. It would represent the rise of a public that is - and perhaps as they should be - sceptical of many forms of power' (Cook \& Gronke, 2005, p. 801).

The principal features characterising the various forms of media differ greatly. Television news is a primary source of information for the general public. This medium influences public opinion (Page, Shapiro \& Dempsey, 1987) and is useful for obtaining information on international affairs (Gunter, 2005). However, given the relatively superficial coverage of news stories on television, viewers perceive that they have learned little and, as a result, feel politically inefficacious (Barthel \& Moy, 2017). The increasing visibility of political conflict through television is likely to exacerbate incivility among citizens, with detrimental effects on political trust (Muzt \& Reeves, 2005). In contrast, Aarts et al.'s (2012) analysis of developed democracies shows that the level of exposure to television news has no effect at all on political trust (see also Ceron, 2015), but much depends on the type of broadcaster (Curran et al., 2014).

It is generally agreed that newspaper exposure is more positively correlated with trust (Ceron, 2015) and other attitudes than exposure to television (Milner, 2002). Its news requires greater attention and, therefore, makes a greater impression on its audience (Graber, 1988). Its influence is due, in part, to the typographical style generated by the effect of printing (Postman, 2000). The press is characterised by more serious analyses and background information (Aarts, Fladmoe \& Strömbäck, 2012), and its readers are better informed than television news viewers (Moy, Torres, Tanaka \& McCluskey, 2005) showing a higher level of political knowledge than those using other media (Elo \& Rapeli, 2010).

Despite its rich history, studies of radio as a medium are primarily undertaken in contexts where television is controlled by a minority. Radio broadcasting provides a useful means of expressing opinions about local political systems and develop a civic sense among listeners (Helge, 1994). In areas where the economy is thriving and collective well-being is evident, competition with other information tools, especially television, is consistent (Waisbord, 2000).

As previously observed, newspapers provide more detailed coverage of news and, therefore, appear more transparent than other traditional forms of media (Moy \& Hussain, 2011), generating greater familiarity and knowledge of political institutions (Armingeon \& Ceka, 2014). Furthermore, the more citizens use newspapers to find out about political institutions, 'the more they concur with newspapers regarding the attributes of the country's political institutions' (Camaj, 2014, p.198). It is, therefore, possible to hypothesise that there is a posi- 
tive nexus between the use of the press to acquire political news and political trust (H1).

The studies on new media have yielded contradictory results (Groshek, 2009) when analysed in terms of political trust. For Diamond (2010), the Internet promotes pluralism in the market for political communication and, as Xenos and Moy (2007) show, tends to weaken the influence of political elites and traditional media. It encourages political interest among those who are not typically engaged (Davis \& Owen, 1998) and may be a tool for either democratisation or authoritarianism (Best \& Wade, 2009), with its effects contingent on the political environment in question (Cho, 2014). Offering a different means of obtaining information (Hill \& Hughes, 1998), use of the internet seems to turn people away from involvement in the political arena (Sunstein, 2001) disconnecting citizens from the political community and fostering critical citizenship (You \& Wang, 2019).

In today's multimedia environment, information is easily distributed on the Internet. The growth of online news has prompted a new set of concerns, as information control is less possible ( $\mathrm{Im}$, Cho, Porumbescu \& Park, 2014) leaving the public with the responsibility of critically evaluating the reliability of online information (McGrew, Breakstone, Ortega, Smith \& Wineburg, 2017). The Internet appears to facilitate the spread of 'fake' news, redefining aspects of political commitment (Dahlgren, 2015) and causing the public to doubt new media and its importance in democratic societies (Gallup \& Knight Foundation, 2017). Given the increasing difficulty for the public in differentiating between false and correct information (Tandoc et al., 2017), the use of the Internet as a source for political news is questionable, as is its ability to contribute to political-institutional support.

Online social networks were not designed specifically to foster political discussion (Papakyriakopoulos, Medina Serrano \& Hegelich, 2020) but studies have, nevertheless, found that they help mobilise citizens (Bajomi-Lazar, 2013) and enable the public to discover, and possibly discuss, the political choices of rulers and the health of democracy (Coleman \& Blumler, 2009). While, for some, use of social media contributes to the public's evaluation of the performance of the political system (Bailard, 2012), for others, the mere use of social media seems unrelated to democratic support (Ceron \& Memoli, 2016) and negatively connected with levels of trust in political institutions (Ceron, 2015). Much depends on the partisan lens used by the public to evaluate the news (see Leeper \& Slothuus, 2014), on party attitudes (Klein \& Robinson, 2020) and on the content of the media more generally (Aalberg, Strömbäck \& de Vreese, 2011).
Since the Internet appears not to facilitate public political support through online social networks, it is possible to hypothesise that the use of the Internet to acquire political news affect negatively political trust $(\mathrm{H} 2)$.

A free media system is indispensable for the media to operate effectively and efficiently within society. Although the media are seen as the 'fourth estate' alongside the executive, legislature and judiciary, they require strong protection from political censorship, the government and other powerful influences so that they can freely reflect the different audiences they serve. With free media system, attempts to manipulate news are less successful (Birch, 2011) and public debate is fuelled (Mouffe, 2009). These aspects allow the public to access the information they need to make informed political choices (O'Neil, 1998) and to influence the political process (Ofcom, 2012) and good governance (Norris, 2004). Like the public, the political environment also benefits from a free media system, which promotes and strengthens the legitimacy of political decisions (Mutz \& Martin, 2001) and facilitates an increase in public trust in political institutions (Zmerli, Newton \& Schmitt-Beck, 2015).

Nevertheless, even with a free media system, the relationship between the media and the political system generally remains problematic. While the public function of the media as a watchdog for public authorities may stimulate the latter to make wise choices, public authorities - even while engaging in media pluralism are simultaneously called upon to regulate the growing media market. The vicious circle between the media and public authorities makes media freedom a major factor in the consolidation of political trust. In many European countries, media freedom is declining (The Economist, 2018), especially in those southern European countries where there is no solid tradition of freedom of the press (Splendore, 2017). Given that 'media restrictions shape the window through which citizens see the political world' (Schedler, 2013, p. 274), it is probable that when countries have free media, citizens' political trust increases (H3).

\section{METHODS, DEPENDENT AND INDEPENDENT VARIABLES}

The hypotheses discussed in the previous section have been tested in 28 European countries using four Eurobarometer surveys. By using a range of data concerning political trust and applying a Polychoric Principal Component Analysis, an additive index was constructed as a synthesis of analysed information (Table 1). 
Tab. 1. Factor analysis.

\begin{tabular}{lc}
\hline & Political Trust \\
\hline Political parties & 0.802 \\
National government & 0.945 \\
National parliament & 0.969 \\
Kaiser - Meyer - Olkin test & 0.721 \\
Barlett's Test (Sig.) & 0.000 \\
Eigenvalue & 2.474 \\
Cronbach's Alpha & 0.800 \\
\hline
\end{tabular}

Source: Eurobarometer 82.3 (2014), 83.4 (2015), 86.2 (2016), 88.3 (2017).

In twenty European countries out of twenty-eight, ${ }^{2}$ between 2014 and 2017 the level of political trust increased (Figure 1), although it remains low in some countries. This trend was true across Europe, from north to south; further, in some of them there were increases in political trust above the European average, including in Portugal, Ireland, Hungary and France, where public opinion, over time, has proved to be more inclined to support political institutions.

In 2017, levels of trust in political institutions with values significantly above the European average were found in Luxembourg, Sweden, the Netherlands and Denmark. On the other hand, in Greece, public opinion appears to be dissatisfied with political institutions, most likely due to the fact that the political choices advanced by the Troika to negotiate the economic crisis reduced the effectiveness of institutions, thereby making them less credible in the eyes of the public.

The six principal independent variables used in the current study are represented by the use of the media to obtain news on national political matters via television, the printed press, radio, the Internet, online social networks, ${ }^{3}$ as well as freedom of the press. ${ }^{4}$ These variables enabled me to test the above hypotheses and assess

\footnotetext{
2 The countries are Austria, the Czech Republic, Greece, Latvia, Lithuania, Malta, Poland, and Romania.

${ }^{3}$ The question was: 'Could you tell me to what extent you... watch television on a TV set, read the written press, listen to the radio, use the Internet, use online social networks?' The answers included 0 'Never', 1 'Less often', 2 'Two or three times a month', 3 'About once a week', 4 'Two or three times a week', 5 'Everyday/Almost every day'. Answers of 'Don't know' were not considered in the analysis.

${ }^{4}$ The Freedom of Press index provides information about media independence and assesses the degree of print, broadcast and digital media freedom among countries and territories. It is characterised by three specific levels: 0 to $30=$ free, 31 to $60=$ partially free, 61 to $100=$ not free. As there are no 'not free' European countries, it was recoded as 0 (partially free) to 1 (free).
}

how media consumption and freedom of the press affected political trust. I tested these hypotheses while controlling for a set of variables commonly used in the literature. First, at the individual level, I considered the sociodemographic variables of gender, ${ }^{5}$ age,${ }^{6}$ education, ${ }^{7}$ occupational status ${ }^{8}$ and social class. ${ }^{9}$ In addition, I considered ideology, ${ }^{10}$ perception of the national economy, ${ }^{11}$ satisfaction with democracy, ${ }^{12}$ political discussion index ${ }^{13}$ and two measures of media trust, one for traditional media and another for new media. ${ }^{14} \mathrm{At}$ an aggregated level, since both economy and institutional quality play a decisive role in political support (Van der Meer \& Hakhverdian 2017), I considered GDP per capita PPP (purchasing power parity; logarithmic value) and Rule of Law. ${ }^{15}$

Table 2 summarises the variables that will be employed in the analysis providing descriptive statistics, while Table 3 reports correlation coefficients among variables. Despite a moderate correlation between Freedom of the Press, Rule of Law and GDP (log), when we remove either the Rule of Law or the GDP (log) from the regression model, the effect of Freedom of the Press on the dependent variable persists.

\section{EMPIRICAL RESULTS}

The multivariate analysis was conducted on a data set combining nearly 54,000 observations at the individual level nested with information at national level. The combination of these two levels of information suggests the use of a multi-level modelling procedure that considers the hierarchical nature of the data and, after running

\footnotetext{
${ }^{5}$ The variable is coded in the following way: $1=$ males, $2=$ females.

${ }^{6}$ The age range is 15 to 99 .

${ }^{7}$ The variable is coded in the following way: $0=$ no full education; $1=$ still studying; $2=<15$ years; $3=16-20$ years; $4=20+$ years.

${ }^{8}$ The variable is coded in the following way: $0=$ self-employed; $1=$ employed; 2 = not working.

${ }^{9}$ The variable (left-right scale) is coded in the following way: $0=$ working class; $1=$ lower class; $2=$ middle class; $3=$ upper class; $4=$ higher class.

${ }^{10}$ The variable is coded in the following way: $1=$ left; $10=$ right.

${ }^{11}$ The variable is coded in the following way: $0=$ very bad + rather bad; $1=$ very good + rather good.

${ }^{12}$ The variable is coded in the following way: $0=$ not at all satisfied + not very satisfied; 1 = fairly satisfied + very satisfied.

${ }^{13}$ This is an additive index which ranges from 0 (where respondents do not discuss political issues at the local, national or European level) to 3 (where respondents discuss political issues at the local, national and/or European level).

${ }^{14}$ These are two additive indexes. While the traditional media index (television, press and radio) ranges from 0 (no trust) to 3 (trust), the new media index (internet and online social network) ranges from 0 (no trust) to 2 (trust).

${ }^{15}$ The values for each variable relate to the year preceding each survey.
} 


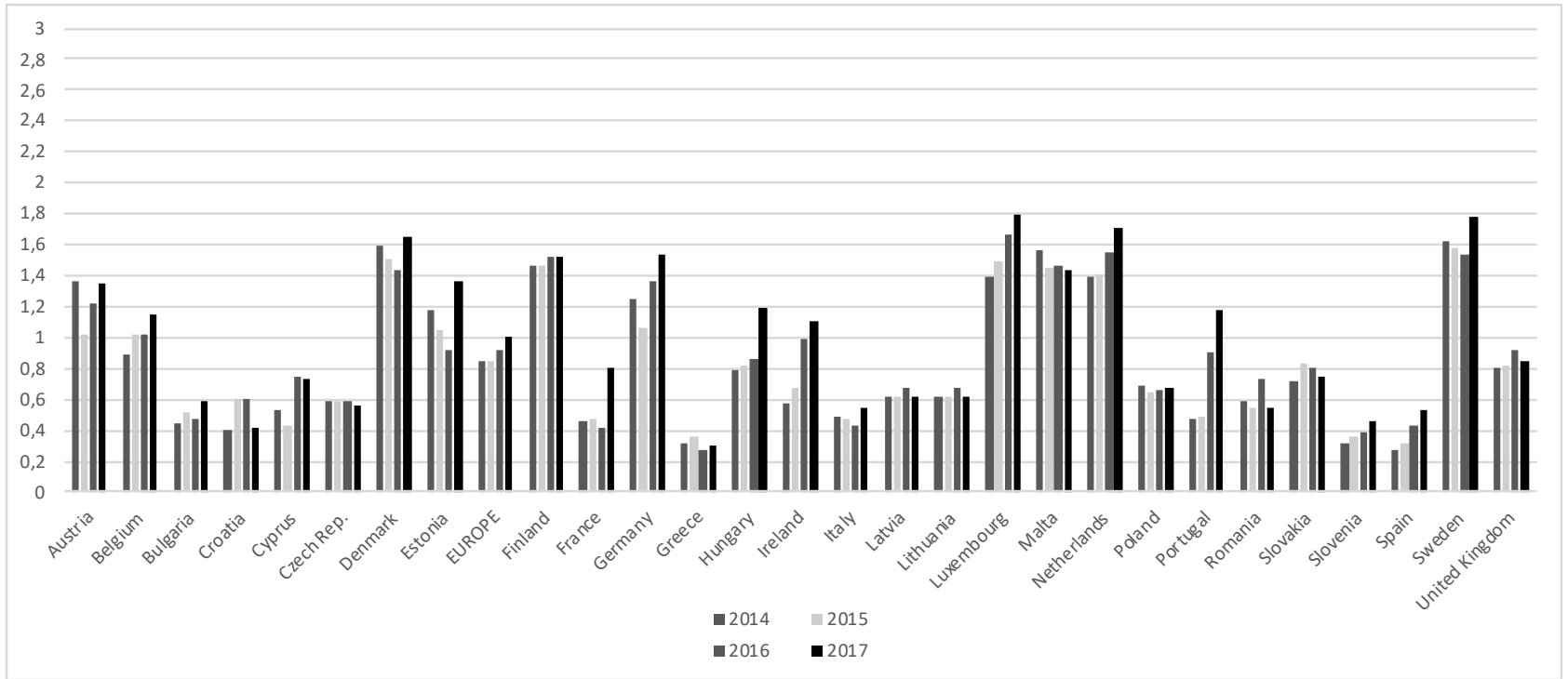

Fig. 1. Political Trust in Europe. Source: Eurobarometer 82.3 (2014), 83.4 (2015), 86.2 (2016), 88.3 (2017).

a Hausman test (prob $>$ chi $2=0.000$ ), we employed a fixedeffect regression model with clustered standard errors. ${ }^{16}$

The first model, reported in Table 3, estimated the effects of traditional forms of media on political trust. The regression model explains $32.3 \%$ of the variance in political trust. As was expected, newspapers appear to increase political trust in the public (H1): this trend is found among those who use this medium at least weekly $(B=0.037)$ and further intensifies when its use becomes daily $(\mathrm{B}=0.055)$. Compared to television and radio, newspapers - precisely because they are more accurate in detailing events - tend to reduce the sensationalist dimension by favouring a neutral and detached representation of the facts. By encouraging greater knowledge and awareness of political facts, newspapers bring the reader closer to institutions, fuelling a sense of political trust even when the political and institutional reality is problematic. This does not occur with television or radio which, for diverse reasons possibly related to programming schedules and short political news shows, rarely appear to increase political trust and, in the case of radio, actually discourage it.

The scenario presented in the new media model (model 2; R-square $=0.275$ ) is bleak: use of the Internet negatively impacts the dependent variable $(\mathrm{H} 2)$ with a $\mathrm{U}$ intensity level, to a greater degree among those who use it sporadically (two or three times a month, $\mathrm{B}=-0.174$ ) or systematically (every day/almost every day; $\mathrm{B}=-0.176$ )

\footnotetext{
${ }^{16}$ Testing for time-fixed effects, the result (Prob $>F=0.737$ ) suggests that one could accept the null hypothesis that the coefficient for all years is jointly equal to zero; therefore, no time-fixed effects were needed.
}

and less intensely among those who use it one or more times a week. From the data, it emerges that the use of the Internet to acquire political news appears to have intensified a distrust of political institutions in one por-

Tab. 2. Descriptive statistics.

\begin{tabular}{lcccc}
\hline & Mean & St. dev. & Min & Max \\
\hline Political trust & 0.903 & 1.149 & 0 & 3 \\
Television & 4,651 & 0.998 & 0 & 5 \\
Press & 3.065 & 1.872 & 0 & 5 \\
Radio & 3.727 & 1.757 & 0 & 5 \\
Website & 3.675 & 2.019 & 0 & 5 \\
Online social network & 2.595 & 2.272 & 0 & 5 \\
Freedom of Press & 0.769 & 0.421 & 0 & 1 \\
Trust traditional media & 1.658 & 1.278 & 0 & 3 \\
Trust new media & 0.768 & 0.861 & 0 & 2 \\
Gender & 1.535 & 0.499 & 1 & 2 \\
Left-right & 5.278 & 2.290 & 1 & 10 \\
Education & 2.926 & 1.084 & 0 & 4 \\
Age & 49.477 & 18.238 & 15 & 99 \\
Satisfaction with democracy & 0.536 & 0.499 & 0 & 1 \\
Political discussion & 2.852 & 1.770 & 0 & 6 \\
Occupation & 2.430 & 0.634 & 1 & 3 \\
Social status & 1.334 & 1 & 0 & 4 \\
Satisfaction with national & 0.770 & 0.421 & 0 & 1 \\
economy & & & & \\
Log Gdp per capita PPP $\left(\mathrm{t}_{-1}\right)$ & 10.382 & 0.330 & 9.680 & 11.461 \\
Rule of Law ( $\mathrm{t}_{-1}$ ) & 1.149 & 0.631 & -0.102 & 2.100 \\
\hline Sorce & & & & \\
\hline
\end{tabular}

Source: Eurobarometer 82.3 (2014), 83.4 (2015), 86.2 (2016), 88.3 (2017), World Bank, World Governance Indicators, Freedom of Press. 
Tab. 3. Correlation matrix.

\begin{tabular}{|c|c|c|c|c|c|c|c|c|c|c|c|c|c|c|}
\hline & $\begin{array}{c}\text { Political } \\
\text { trust }\end{array}$ & Television & Press & Radio & Website & $\begin{array}{c}\text { Online } \\
\text { social } \\
\text { network }\end{array}$ & $\begin{array}{c}\text { Trust } \\
\text { traditional } \\
\text { media }\end{array}$ & $\begin{array}{l}\text { Trust } \\
\text { new } \\
\text { media }\end{array}$ & Gender & $\begin{array}{l}\text { Left- } \\
\text { right }\end{array}$ & Education & Age & $\begin{array}{c}\text { Satisfaction } \\
\text { with } \\
\text { democracy }\end{array}$ & $\begin{array}{c}\text { Political } \\
\text { discussion }\end{array}$ \\
\hline Political trust & t 1.000 & & & & & & & & & & & & & \\
\hline Television & -0.001 & 1.000 & & & & & & & & & & & & \\
\hline Press & 0.195 & 0.096 & 1.000 & & & & & & & & & & & \\
\hline Radio & 0.086 & 0.130 & 0.334 & 1.000 & & & & & & & & & & \\
\hline Website & 0.062 & 0.062 & 0.140 & 0.155 & 1.000 & & & & & & & & & \\
\hline $\begin{array}{l}\text { Online social } \\
\text { network }\end{array}$ & 0.026 & -0.074 & 0.001 & 0.044 & 0.591 & 1.000 & & & & & & & & \\
\hline $\begin{array}{l}\text { Trust } \\
\text { traditional } \\
\text { media }\end{array}$ & 0.400 & 0.083 & 0.201 & 0.129 & 0.064 & 0.0281 & 1.000 & & & & & & & \\
\hline $\begin{array}{l}\text { Trust new } \\
\text { media }\end{array}$ & 0.160 & 0.008 & -0.011 & 0.014 & 0.159 & 0.212 & 0.309 & 1.000 & & & & & & \\
\hline Gender & -0.025 & 0.033 & -0.062 & -0.038 & -0.009 & 0.065 & 0.026 & -0.002 & 1.000 & & & & & \\
\hline Left-right & 0.032 & 0.027 & 0.001 & 0.011 & 0.009 & 0.006 & 0.019 & 0.045 & -0.037 & 1.000 & & & & \\
\hline Education & 0.056 & 0.067 & 0.166 & 0.148 & 0.122 & -0.024 & 0.044 & 0.001 & 0.010 & 0.022 & 1.000 & & & \\
\hline Age & 0.056 & 0.189 & 0.200 & 0.088 & -0.371 & -0.481 & 0.028 & -0.142 & -0.034 & -0.003 & 0.232 & 1.000 & & \\
\hline $\begin{array}{l}\text { Satisfaction } \\
\text { with } \\
\text { democracy }\end{array}$ & 0.436 & 0.010 & 0.179 & 0.096 & 0.098 & 0.041 & 0.298 & 0.060 & -0.013 & 0.040 & 0.054 & 0.034 & 1.000 & \\
\hline $\begin{array}{l}\text { Political } \\
\text { discussion }\end{array}$ & 0.089 & 0.007 & 0.221 & 0.132 & 0.090 & -0.003 & 0.038 & 0.017 & -0.085 & -0.010 & 0.136 & 0.138 & 0.043 & 1.000 \\
\hline Occupation & -0.008 & 0.029 & -0.040 & -0.104 & -0.210 & -0.159 & -0.013 & -0.081 & 0.079 & 0.053 & -0.329 & 0.227 & -0.018 & -0.047 \\
\hline Social status & 0.175 & -0.061 & 0.168 & 0.086 & 0.214 & 0.106 & 0.117 & 0.050 & 0.003 & 0.081 & 0.164 & -0.019 & 0.170 & 0.148 \\
\hline $\begin{array}{l}\text { Satisfaction } \\
\text { with national } \\
\text { economy }\end{array}$ & 0.407 & -0.036 & 0.185 & 0.102 & 0.101 & 0.032 & 0.227 & 0.020 & -0.049 & 0.028 & 0.066 & 0.044 & 0.434 & 0.091 \\
\hline $\begin{array}{l}\text { Freedom of } \\
\text { Press }\end{array}$ & 0.400 & 0.141 & -0.055 & 0.224 & 0.158 & 0.148 & 0.131 & -0.120 & -0.012 & -0.056 & 0.054 & 0.074 & 0.197 & 0.007 \\
\hline $\begin{array}{l}\text { Log Gdp per } \\
\text { capita PPP } \\
\left(\mathrm{t}_{-1}\right)\end{array}$ & 0.240 & -0.046 & 0.275 & 0.176 & 0.161 & 0.018 & 0.117 & -0.168 & -0.042 & -0.074 & 0.067 & 0.117 & 0.285 & 0.056 \\
\hline $\begin{array}{l}\text { Rule of Law } \\
\left(t_{-1}\right)\end{array}$ & 0.264 & -0.058 & 0.320 & 0.179 & 0.191 & 0.029 & 0.158 & -0.174 & -0.038 & -0.057 & 0.088 & 0.128 & 0.312 & 0.074 \\
\hline
\end{tabular}

\begin{tabular}{|c|c|c|c|c|c|c|c|}
\hline & $\begin{array}{l}\text { Political } \\
\text { discussion }\end{array}$ & Occupation & Social status & $\begin{array}{l}\text { Satisfaction } \\
\text { with national } \\
\text { economy }\end{array}$ & Freedom of Press & $\begin{array}{l}\text { Log Gdp per } \\
\text { capita PPP }\left(\mathrm{t}_{-1}\right)\end{array}$ & Rule of Law $\left(t_{-1}\right)$ \\
\hline $\begin{array}{l}\text { Political } \\
\text { discussion }\end{array}$ & 1.000 & & & & & & \\
\hline Occupation & -0.047 & 1.000 & & & & & \\
\hline Social status & 0.148 & -0.111 & 1.000 & & & & \\
\hline $\begin{array}{l}\text { Satisfaction } \\
\text { with national } \\
\text { economy }\end{array}$ & 0.091 & -0.021 & 0.205 & 1.000 & & & \\
\hline Freedom of Press & 0.007 & 0.042 & 0.040 & 0.245 & & & \\
\hline $\begin{array}{l}\text { Log Gdp per } \\
\text { capita PPP }\left(t_{-1}\right)\end{array}$ & 0.056 & 0.046 & 0.144 & 0.360 & 0.611 & 1.000 & \\
\hline Rule of Law $\left(t_{-1}\right)$ & 0.074 & 0.055 & 0.115 & 0.375 & 0.766 & 0.853 & 1.000 \\
\hline
\end{tabular}

Eurobarometer 82.3 (2014), 83.4 (2015), 86.2 (2016), 88.3 (2017), World Bank, World Governance Indicators, Freedom of Press. 
tion of the population, possibly due to the quality of information disseminated through this medium (the control of which remains problematic), and to the tendency to select only information that strengthens an existing opinion. At the same time, online social networks appear to reduce political trust only when they are used daily or almost daily $(\mathrm{B}=-0.038)$.

From the first two models, it is clear that not all forms of media contribute to encouraging support of democratic institution: both traditional and new media are found to constitute, in some cases, an obstacle rather than an aid to the consolidation of democracy.

Model 3 estimates the effect of media freedom on the political confidence index $(\mathrm{R}$-square=30.5). Although freedom of the media is more fragile today than any time since the end of the Cold War, it continues to be decisive in nourishing the public's sense of trust in political institutions $(\mathrm{H} 3 ; \mathrm{B}=0.109)$. The strength of independent news media contributes significantly to the formation of public opinion, allowing people to make informed choices in their political decisions. Nevertheless, the legitimatising effect of media pluralism on the political process does not seem to characterise all EU countries; this is particularly evident in those countries ${ }^{17}$ where, over time, the media system has been subject to significant restrictions (Freedom of the Press, 2017; Repucci, 2020).

Model 4 uses all six independent variables and explains $30.8 \%$ of the variance in political trust; all hypotheses were confirmed. Forms of both new and old media were found to produce differentiated effects on political trust. Among these, newspapers and the Internet appear to be the cornerstones on which political trust can be established, consolidated or eroded. Much depends on the frequency of use and the context in which the media operate. When the media system is only partially free, citizens appear to distance themselves from their political institutions by becoming more critical and disheartened because the media no longer adequately represent the diversified perspectives and interests in the societies where they operate. Furthermore, the limits that oppose their freedom tend to cause public perceptions of political institutions to worsen. Television, radio and online social networks, whose effects on the dependent variable are rarely statistically significant, appear to contribute little to political trust. In conclusion, in the European media, where some political leaders have silenced critical media and strengthened those that offer favourable coverage (Repucci 2020), freedom of the press has become a luxury rather than the norm and the legitimising role of the institutions is

${ }^{17}$ The countries are Bulgaria, Croatia, Greece, Italy, Poland and Romania. conveyed by the press and the Internet, which are able to bring citizens closer (in the case of the former) or further away (in the case of the latter) from their political institutions.

By checking these effects on the dependent variable using sociodemographic, economic and political indicators, I found that those with higher levels of education had less negative attitudes towards political institutions. If education encourages the public to be more critical of institutions, the perception of well-being gives them greater optimism and a greater propensity to trust in political institutions. Indeed, whether we consider the national economy, real $(B=0.467)$ or perceived $(B=0.439)$, or whether we look at the social status of the respondents, with the exception of the 'middle-lower class', trust in political institutions is more than positive. This is clearly not always the case: when the system of rules that governs the exercise of public power becomes more rigorous, citizens tend to rely less on political institutions $(\mathrm{B}=-0.346)$.

If it is true that trust generates trust among individuals (Putnam, 1993), the same connection can be found at the institutional level: when citizens trust in media, the level of political trust increase (traditional media: $B=0.209$, new media: $B=0.133$ ). The same scenario emerges when looking at the involvement of citizens in the political arena, whether at the level of discussing issues $(B=0.015)$ or at a more general evaluation of the political system, i.e. satisfaction with the functioning of democracy $(B=0.532)$.

In conclusion, a fluctuating level of political trust could prove acceptable, as institutions are not always able to achieve acceptable performance levels. However, not all types of media appear to facilitate the efforts of political institutions because, in some cases, as with the press or the Internet, they may amplify political and institutional criticalities and, hence, fuel public distrust.

\section{CONCLUSION}

In recent years, the economic and migration crises have caused the already tense relationship between citizens and political institutions to be questioned. Citizens in Western democracies seem to be experiencing a democratic malaise towards their political systems (Norris, 2011); indeed, a crisis of governability characterises numerous consolidated democracies (Kupchan, 2012). Lower standards of living, job insecurity and growing socioeconomic inequality are increasingly stimulating citizens to demand a more appropriate response from their institutions. 
Tab. 4. Political Trust - Linear Fixed Regression Model.

\begin{tabular}{|c|c|c|c|c|c|c|c|c|c|c|c|c|}
\hline & \multicolumn{3}{|c|}{ Model 1} & \multicolumn{3}{|c|}{ Model 2} & \multicolumn{3}{|c|}{ Model 3} & \multicolumn{3}{|c|}{ Model 4} \\
\hline & Coeff. & & $\begin{array}{c}\text { Rob. Std. } \\
\text { Err. }\end{array}$ & Coeff. & & $\begin{array}{c}\text { Rob. Std. } \\
\text { Err. }\end{array}$ & Coeff. & & $\begin{array}{c}\text { Rob. Std. } \\
\text { Err. }\end{array}$ & Coeff. & & $\begin{array}{c}\text { Rob. Std. } \\
\text { Err. }\end{array}$ \\
\hline \multicolumn{13}{|l|}{ Micro level } \\
\hline \multicolumn{13}{|l|}{$\operatorname{Tv}$ (never) } \\
\hline less often & -0.005 & & 0.032 & & & & & & & 0.017 & & 0.033 \\
\hline two or three times a month & 0.999 & $* *$ & 0.042 & & & & & & & 0.107 & $* *$ & 0.043 \\
\hline about once a week & 0.035 & & 0.033 & & & & & & & 0.051 & & 0.032 \\
\hline two or three times a week & 0.021 & & 0.026 & & & & & & & 0.042 & & 0.026 \\
\hline everydaylalmost every day & -0.0026 & & 0.021 & & & & & & & -0.002 & & 0.022 \\
\hline \multicolumn{13}{|l|}{ Press (never) } \\
\hline less often & -0.010 & & 0.018 & & & & & & & -0.003 & & 0.017 \\
\hline two or three times a month & -0.003 & & 0.026 & & & & & & & -0.000 & & 0.024 \\
\hline about once a week & 0.037 & * & 0.019 & & & & & & & 0.044 & $* *$ & 0.020 \\
\hline two or three times a week & 0.034 & * & 0.017 & & & & & & & 0.043 & $* *$ & 0.017 \\
\hline everydaylalmost every day & 0.055 & $* * *$ & 0.023 & & & & & & & 0.070 & $* * *$ & 0.021 \\
\hline \multicolumn{13}{|l|}{ Radio (never) } \\
\hline less often & -0.022 & & 0.023 & & & & & & & -0.018 & & 0.023 \\
\hline two or three times a month & -0.060 & $* *$ & 0.026 & & & & & & & -0.055 & $* *$ & 0.026 \\
\hline about once a week & -0.011 & & 0.017 & & & & & & & -0.006 & & 0.018 \\
\hline two or three times a week & -0.031 & & 0.021 & & & & & & & -0.028 & & 0.020 \\
\hline everyday $\backslash$ almost every day & -0.045 & * & 0.024 & & & & & & & -0.033 & & 0.023 \\
\hline \multicolumn{13}{|l|}{ Internet (never) } \\
\hline less often & & & & -0.034 & & 0.038 & & & & -0.029 & & 0.033 \\
\hline two or three times a month & & & & -0.174 & $* * *$ & 0.044 & & & & -0.163 & $* * *$ & 0.047 \\
\hline about once a week' & & & & -0.120 & $* * * *$ & 0.027 & & & & -0.119 & $* * * *$ & 0.026 \\
\hline two or three times a week & & & & -0.138 & $* * * *$ & 0.030 & & & & -0.141 & $* * * *$ & 0.031 \\
\hline everydaylalmost every day & & & & -0.176 & $* * * *$ & 0.035 & & & & -0.161 & $* * * *$ & 0.035 \\
\hline \multicolumn{13}{|l|}{ Online social network (never) } \\
\hline less often & & & & 0.004 & & 0.020 & & & & 0.006 & & 0.020 \\
\hline two or three times a month & & & & 0.040 & & 0.034 & & & & 0.046 & & 0.035 \\
\hline about once a week & & & & 0.036 & & 0.024 & & & & 0.040 & * & 0.021 \\
\hline two or three times a week & & & & -0.003 & & 0.019 & & & & -0.003 & & 0.019 \\
\hline everyday\almost every day & & & & -0.038 & $* *$ & 0.017 & & & & -0.001 & & 0.019 \\
\hline Gender & -0.018 & & 0.012 & 0.007 & & 0.013 & -0.015 & & 0.012 & -0.012 & & 0.012 \\
\hline \multicolumn{13}{|l|}{ Education (no full-time education) } \\
\hline still studying & 0.014 & & 0.107 & -0.109 & & 0.117 & -0.009 & & 0.113 & -0.028 & & 0.115 \\
\hline$<15$ & -0.165 & $* * *$ & 0.048 & -0.225 & $* * * *$ & 0.050 & -0.171 & $* * *$ & 0.050 & -0.188 & $* * *$ & 0.049 \\
\hline $16-20$ years & -0.142 & $* * * *$ & 0.032 & -0.187 & $* * * *$ & 0.037 & -0.159 & $* * * *$ & 0.034 & -0.153 & $* * * *$ & 0.032 \\
\hline $20+$ years & -0.076 & $* *$ & 0.029 & -0.106 & $* * *$ & 0.031 & -0.090 & $* * *$ & 0.031 & -0.078 & ** & 0.031 \\
\hline Age & 0.002 & $* *$ & 0.001 & 0.002 & $* *$ & 0.001 & 0.002 & $* * *$ & 0.001 & 0.001 & & 0.001 \\
\hline \multicolumn{13}{|l|}{ Occupation (self-employed) } \\
\hline Employed & -0.020 & & 0.021 & 0.007 & & 0.019 & -0.015 & & 0.019 & -0.014 & & 0.020 \\
\hline not working & -0.021 & & 0.023 & -0.018 & & 0.020 & -0.016 & & 0.023 & -0.022 & & 0.022 \\
\hline
\end{tabular}




\begin{tabular}{|c|c|c|c|c|c|c|c|c|c|c|c|c|}
\hline & \multicolumn{3}{|c|}{ Model 1} & \multicolumn{3}{|c|}{ Model 2} & \multicolumn{3}{|c|}{ Model 3} & \multicolumn{3}{|c|}{ Model 4} \\
\hline & Coeff. & & $\begin{array}{l}\text { Rob. Std. } \\
\text { Err. }\end{array}$ & Coeff. & & $\begin{array}{l}\text { Rob. Std. } \\
\text { Err. }\end{array}$ & Coeff. & & $\begin{array}{l}\text { Rob. Std. } \\
\text { Err. }\end{array}$ & Coeff. & & $\begin{array}{l}\text { Rob. Std. } \\
\text { Err. }\end{array}$ \\
\hline \multicolumn{13}{|l|}{ Social status (the working class of society) } \\
\hline the lower middle class of society & 0.026 & & 0.024 & 0.039 & & 0.026 & 0.024 & & 0.025 & 0.030 & & 0.024 \\
\hline the middle class of society & 0.055 & $* *$ & 0.024 & 0.080 & $* * *$ & 0.027 & 0.054 & $* *$ & 0.025 & 0.062 & ** & 0.025 \\
\hline the upper middle class of society & 0.144 & $* * *$ & 0.047 & 0.190 & $* * *$ & 0.051 & 0.148 & $* * *$ & 0.048 & 0.153 & $* * *$ & 0.048 \\
\hline the higher class of society & 0.117 & * & 0.072 & 0.155 & $* *$ & 0.073 & 0.116 & & 0.075 & 0.126 & * & 0.072 \\
\hline National economy & 0.448 & $* * * *$ & 0.028 & 0.489 & $* * * *$ & 0.030 & 0.443 & $* * * *$ & 0.027 & 0.439 & $* * * *$ & 0.027 \\
\hline Left-right & 0.005 & & 0.008 & 0.004 & & 0.009 & 0.004 & & 0.009 & 0.005 & & 0.009 \\
\hline Satisfaction with democracy & 0.540 & $* * * *$ & 0.034 & 0.635 & $* * * *$ & 0.045 & 0.533 & $* * * *$ & 0.034 & 0.532 & $* * * *$ & 0.034 \\
\hline Political discussion index & 0.014 & $* * *$ & 0.003 & 0.017 & $* * * *$ & 0.004 & 0.014 & $* * * *$ & 0.004 & 0.015 & $* * *$ & 0.003 \\
\hline Trust in traditional media & 0.239 & $* * * *$ & 0.013 & & & & 0.211 & $* * * *$ & 0.014 & 0.209 & $* * * *$ & 0.014 \\
\hline Trust in new media & & & & 0.234 & $* * * *$ & 0.016 & 0.122 & $* * * *$ & 0.013 & 0.133 & $* * * *$ & 0.013 \\
\hline \multicolumn{13}{|l|}{ Macro level } \\
\hline Freedom of Press & & & & & & & 0.109 & $* * *$ & 0.028 & 0.103 & $* * *$ & 0.028 \\
\hline Log GDP per capita PPP & & & & & & & 0.411 & & 0.264 & 0.467 & * & 0.246 \\
\hline Rule of Law & & & & & & & -0.345 & $* *$ & 0.144 & -0.346 & $* *$ & 0.142 \\
\hline Constant & -0.010 & & 0.067 & 0.251 & $* * *$ & 0.084 & -4.049 & & 2.800 & -4.459 & * & 2.604 \\
\hline Sigma_u & 0.184 & & & 0.232 & & & 0.251 & & & 0.248 & & \\
\hline Sigma_e & 0.935 & & & 0.958 & & & 0.930 & & & 0.928 & & \\
\hline Rho & 0.037 & & & 0.056 & & & 0.068 & & & 0.066 & & \\
\hline R square & 0.323 & & & 0.275 & & & 0.305 & & & 0.308 & & \\
\hline Number of observations & 53,922 & & & 53,922 & & & 53,922 & & & 53,922 & & \\
\hline Number of countries & 28 & & & 28 & & & 28 & & & 28 & & \\
\hline
\end{tabular}

Note: The robust standard errors have been adjusted for 28 cluster (countries); ${ }^{\star} \mathrm{p}<0.10,{ }^{* *} \mathrm{p}<0.05,{ }^{* *} \mathrm{p}<0.01,{ }^{* * * *} \mathrm{p}<0.001$. Source: Eurobarometer 82.3 (2014), 83.4 (2015), 86.2 (2016), 88.3 (2017), World Bank, World Governance Indicators, Freedom of Press.

Among the determinants of political trust, some forms of media seem to play a salient role. Studies have considered the impacts of the media in different political regimes, highlighting the diverse effects that old and new forms of media generate within the public domain. However, no study has yet examined the effect of both traditional and new media on levels of political trust. This article has thus sought to contribute to existing knowledge by providing an account of the dynamic interrelationship between the media and political support.

Using Eurobarometer data collected from 2014 to 2017, this study found that, in European countries, political institutions can achieve appreciable levels of performance. Support for political institutions is as high as ever in Scandinavian countries but, in southern European countries (with a few exceptions), political institutions are struggling to meet citizens' demands.

Comparisons between traditional and new media reveal a clear lack of homogeneity within the individual conceptual labels that aggregate television, radio and the press, on one side, and the Internet and online social networks, on the other. The contrast that emerges between newspapers, on the one hand, and the Internet, on the other, encapsulates how little the distinction between traditional and new media has diminished in the last four years, rendering the media galaxy much more articulate. Although for some scholars the new media are characterised by deference to authority (Donohue, Tichenor \& Olien, 1995), favouring topics and interpretations proposed by government officials while neglecting alternative voices (Bennett, Lawrence \& Livingston, 2007), the results of this study are more nuanced. As was expected, where the media system is free, media outlets are able to play a key role in bringing citizens closer to politics (as in the case of the press) or making them more critical, sceptical and disheartened (as in the case of the Internet) (Fletcher \& Nielsen, 2018).

A limitation of this work lies in the absence of information in the data-set used that would have enabled me to evaluate the slant of the news, a crucial factor in fully 
understanding the effects of the media on political support. Future research could consider these aspects by examining the differences between traditional and new media, as well as expanding the number of cases and the time frame.

\section{ACKNOWLEDGEMENTS}

I am grateful to Andrea Ceron and two anonymous reviewers for their insightful and helpful suggestions.

\section{REFERENCES}

Aalberg, T., Strömbäck, J., \& de Vreese, C. H. (2011). The framing of politics as strategy and game: A review of concepts, operationalizations and key findings. Journalism, 13(2), 162-178.

Aarts, K., Fladmoe, A. \& Strömbäck, J. (2012). Media, Political Trust, and Political Knowledge: A Comparative Perspective, in T. Aalberg \& J. Curran (Eds.) How Media Inform Democracy. A Comparative Approach, (pp. 98-118). London: Routledge.

Almond, G., \& Verba. S. (1963). The civic culture: Political attitudes and democracy in five nations. Princeton: Princeton University Press.

André, S. (2014). Does trust mean the same for migrants and natives? Testing measurement models of political trust with multi-group confirmatory factor analysis. Social Indicators Research, 115(3), 963-982.

Bailard, C.S. (2012). Testing the Internet's effect on democratic satisfaction: A multi-methodological,crossnational approach .Journal of Information Technology \& Politics, 9, 185-204.

Bajomi-Lazar, P. (2013). From Political Propaganda to Political Marketing. Changing Patterns of Political Communication in Central and Eastern Europe, in P. Gross \& K. Jakubowicz (Eds.) Media Transformations in the Post-Communist World: Eastern Europe's Tortured Path to Change (pp. 49-66). Plymouth, UK: Lexington Books.

Barthel, M., \& Moy, P. (2017). The Media and the Fostering of Political (Dis)Trust, in K. Kensi \& K. H. Jamieson (Eds), The Oxford Handbook of Political Communication (pp. 581-594), New York: Oxford University Press.

Bennett, W., Lawrence, R. and Livingston, S. (2007). When the press fails: Political power and the news media from Iraq to Katrina. Chicago, IL: University of Chicago Press.

Best, M., \& Wade, K. (2009). The Internet and Democracy Global Catalyst or Democratic Dud?. Bulletin of Science, Technology \& Society, 29(4), 255-271.
Birch, S. (2011). Electoral malpractice. Oxford, New York: Oxford University Press.

Brosius, A., van Elsas, E. J., \& de Vreese, C. H. (2019). How media shape political trust: News coverage of immigration and its effects on trust in the European Union. European Union Politics, 20(3), 447-467

Camaj, L. (2014). Media use and political trust in an emerging democracy: Setting the institutional trust agenda in Kosovo. International Journal of Communication, 8, 187-209.

Ceron, A. (2015) Internet, News, and Political Trust: The Difference Between Social Media and Online Media Outlets. Journal of Computer-Mediated Communication, 20, 487-503.

Ceron, A., \& Memoli, V. (2016) Flames and Debates: Do Social Media Affect Satisfaction with Democracy?. Social Indicator Research 126, 225-240.

Cho, Y. (2014). Internet and Democratic Citizenship among the Global Mass Publics: Does Internet Use Increase Political Support for Democracy?. Japanese Journal of Political Science, 15(4), 661-682.

Coleman, S., \& Blumler, J. (2009). The Internet and Democratic Citizenship: Theory, Practice and Policy. Communication, Society and Politics. Cambridge: Cambridge University Press.

Cook, T., \& Gronke, P. (2005). The sceptical American: Revisiting the meanings of trust in government and confidence in institutions. Journal of Politics 67(3): 784-803.

Curran, J., Coen, S. Soroka, S., Aalberg, T., Hayashi, K., Hichy, Z., \& Tiffen, R. (2014). Reconsidering 'Virtuous Circle' and 'Media Malaise' Theories of the Media: An 11-Nation Study. Journalism, 15(7), 815-33.

Czepek, A., Hellwig, M., \& Nowak, E. (2009). Press Freedom and Pluralism in Europe: Concepts and Conditions. Chicago: University of Chicago Press Books.

Dahlgren, P. (2009). Media and Political Engagement: Citizens, Communication, and Democracy. Cambridge: Cambridge University Press.

Dahlgren, P. (2015). The internet as a civic space, in S. Coleman \& D. Freelon (Eds.) Handbook of digital politics (pp. 17-34). Cheltenham, UK: Edward Elgar Publishing Ltd.

Davis, R., \& Owen, D. (1998). New media and American politics. Oxford: Oxford University Press.

Denters, B., Gabriel, O., \& Torcal, M. (2007). Political Confidence in Representative Democracies: SocioCultural vs. Political Explanations, in J. Van Deth, J. Montero, \& A. Westholm (Eds.) Citizenship and Involvement in European Democracies: A Comparative Analysis (pp. 66-87). London \& New York: Routledge.

Diamond, L. (2010). Liberation Technology. Journal of Democracy, 21(3), 69-83. 
Donohue, G., Tichenor, P., \& Olien, C. (1995). A guard dog perspective on the role of media. Journal of Communication, 45(2), 115-132.

Easton, D. (1965). A system analysis of political life. New York: Wiley.

Elo, K., \& Rapeli, L. (2010). Determinants of Political Knowledge: The Effects of the Media on Knowledge and Information. Journal of Elections, Public Opinion and Parties, 20(1), 133-146.

Fletcher, R., \&.Nielsen, R. (2018). Generalised scepticism: how people navigate news on social media. Information, Communication \& Society, 0(0), 1-19.

Freedom of the Press (2017). Freedom of the Press index. Retrieved from https://freedomhouse.org/reports/ publication-archives.

Fryberg, S.A., Stephens, N.M, Covarrubias, R., Markus, H.R., Carter, E.D., Laiduc, G.A., \& Salido, A.J. (2012). How the Media Frames the Immigration Debate: The Critical Role of Location and Politics. Analyses of Social Issues and Public Policy, 12, 96-112.

Gallup and Knight Foundation. (2017). American views: Trust, Media and Democracy. Whashington DC: Gallup Inc. Retrieved from https://knightfoundation.org/ reports/american-views-trust-media-and-democracy.

Gamson, W.A. (1968). Power and discontent. Homewood, IL: Dorsey Press.

Graber, D. (1988). Processing the news: How people tame the information tide. New York: Longman.

Groshek, J. (2009). The Democratic Effects of the Internet, 1994-2003. International Communication Gazette, 71(3), 115-136.

Gross, K., Aday, S., \& Brewer, P. R. (2004). A Panel Study of Media Effects on Political and Social Trust after September 11, 2001. Harvard International Journal of Press/Politics, 9(4), 49-73.

Gunter, B. (2005). Trust in the news on television. Aslib Proceedings, 57(5), 384-397.

Gunther, R., \& Mughan, A. (2000). Democracy and the Media: A Comparative Perspective. Cambridge: Cambridge University Press.

Helge, R. (1994). Media and democracy: theories and principles with reference to an African context. Harare: SAPES Books.

Hetherington, M.J. (1998). The Political Relevance of Political Trust. The American Political Science Review, 92(4), 791-808.

Hill, K., \& Hughes, J. (1998). Cyberpolitics: Citizen Activism in the age of the Internet. Lanham: Rowman \& Littlefield.

Hooghe, M. (2011). Why There is Basically Only One Form of Political Trust. British Journal of Politics \& International Relations, 13(2), 269-275.
Im, T., Cho, W., Porumbescu, G., \& Park, G. (2014). Internet, Trust in Government, and Citizen Compliance. Journal of Public Administration Research and Theory, 24(3): 741-763.

Journalisti (2017). Painostuksenn monet muodot. Retrieved from https://www.journalisti.fi/artikkelit/2017/7/painostuksen-monet-muodot/

Kaase, M. (1999). Interpersonal trust, political trust and non-institutionalised political participation in Western Europe. West European Politics, 22(3), 1-21.

Kellner, D. (2004). The Media and Social Problems, in G. Ritzer (ed.) Handbook of Social Problems: A Comparative International Perspective (pp. 209-225). London: Sage.

Klein, E. \& Robison, J. (2020). Like, Post, and Distrust? How Social Media Use Affects Trust in Government, Political Communication, 37:1, 46-64

Kleinnijenhuis, J., van Hoof, A., \& Oegema, D. (2006). Negative news and the sleeper effect of distrust. International Journal of Press and Politics, 11(2), 86-104.

Kroknes, F., Jakobsen, T., \& Grønning, L. (2016). Economic Performance and Political Trust: The impact of the financial crisis on European citizens. European Societies, 17(5), 700-723.

Kupchan, C. (2012). The Democratic Malaise: Globalization and the Threat to the West. Foreign Affairs, 91(1), 62-67.

Leeper, T.J., \& Slothuus, R. (2014) Political parties, motivated reasoning, and public opinion formation. Advances in Political Psychology 35(1): 129-156

Leeson, P. (2008). Media Freedom, Political Knowledge, and Participation. Journal of Economic Perspectives, 22(2), 155-169.

Levi, M., \& Stoker, L. (2000). Political trust and trustworthiness. Annual Review of Political Science, 3(1), 475507.

Manin, B. (1995). Principes du gouvernement représentatif. Paris: Flammarion.

McCombs, M. (2004). Setting the agenda: The mass media and public opinion. Malden, MA: Blackwell.

McGrew S., Breakstone J., Ortega T., Smith M., \& Wineburg, S. (2018) Can students evaluate online sources? Learning from assessments of civic online reasoning. Theory \& Research in Social Education, 46(2):1-29.

Memoli, V., \& Splendore, S. (2014). Media use and confidence in institutions: a comparative analysis of the three Hallin and Mancini's models. Rivista Italiana di Scienza Politica, 44 (2), 175-192.

Milner, H. (2002). Civic Literacy: How Informed Citizens Make Democracy Work. Hanover: University Press of New England. 
Mishler, W., \& Rose, R. (2001). What Are the Origins of Political Trust? Testing Institutional and Cultural Theories in Post-Communist Societies. Comparative Political Studies, 34(1), 30-62.

Mouffe, C. (2009). Democracy in a Multipolar World. Millennium. Journal of International Studies, 37(3), 549-561.

Moy, P., Torres, M., Tanaka, K., \& McCluskey, M. (2005). Knowledge or Trust? Investigating Linkages Between Media Reliance and Participation. Communication Research, 32(1), 59-86.

Moy, P, \& Hussain M.M. (2011). Media influences on political trust and engagement. In Edwards GC, Jacobs LR \& Shapiro RY (Eds) The Oxford Handbook of American Public Opinion and the Media (pp. 1-21). Oxford: Oxford University Press.

Mutz, D., \& Martin, P. (2001). Facilitating Communication across Lines of Political Difference: The Role of Mass Media. American Political Science Review, 95(1), 97-114.

Mutz, D., \& Reeves, B. (2005). The new videomalaise: Effects of television incivilty on political trust. The American Political Science Review, 99(1), 1-15.

Newton, K. (2001). Trust, social capital, civil society, and democracy. International Political Science Review, 22(2), 201-214.

Newton, K. (2007). Social and political trust, in R. Dalton \& H. Klingemann (Eds.) The Oxford Handbook of Political Behavior (pp. 342-361). Oxford: Oxford University Press.

Norris, P. (Ed.) (1999). Critical Citizens: Global Support for Democratic Governance. Oxford: Oxford University Press.

Norris, P. (2004). Global political communication: Good governance, human development, and mass communication, in F. Esser, \& B. Pfetsch (Eds.) Comparing Political Communication: Theories, Cases, Challenges (pp. 115-150). Cambridge: Cambridge University Press.

Norris, P. (2011). Democratic deficit: Critical citizens revisited. New York, NY: Cambridge University Press.

Ofcom. (2012). Communications Market Report. London: Ofcom.

O'Neil, P. (1998). Communicating democracy: the media and political transitions. Boulder, CO: Lynne Rienner.

Page, B., Shapiro, R., \& Dempsey, G. (1987). What Moves Public Opinion?' American Political Science Review, 81(3), 23-43.

Papakyriakopoulos, O., Medina Serrano, J.C. and Hegelich, S: (2020). Political communication on social media: A tale of hyperactive users and bias in recommender systems. Online Social Networks and Media, 15.
Postman, N. (2000). The humanism of media ecology. Procedings of the Media Ecology Association, 1, 10-16.

Putnam R. (1993). Making Democracy Work: Civic Tradition in Modern Italy. NY: Princeton University Press.

Repucci, S. (2020). Freedom and the Media 2019. Freedom: A Downward Spiral. Retrived from https:// freedomhouse.org/report/freedom-and-media/2019/ media-freedom-downward-spiral.

Rodrìguez, M. and Zechmeister, E.J. (2018). Media Pluralism, Public Trust, and Democracy: New Evidence from Latin America and the Carribbean. Washington DC: CIMA.

Rothstein, B., \& Stolle, D. (2008). The State and Social Capital: An Institutional Theory of Generalized Trust. Comparative Politics, 40(4), 441-459.

Schedler, A. (2013). The politics of uncertainty: Sustaining and subverting electoral authoritarianism. Oxford, New York: Oxford University Press.

Splendore, S. (2017). Media Use: Southern Europe, in P. Rössler, C. Hoffner and L. van Zoonen (eds) The International Encyclopedia of Media Effects (pp. 1-10). Hoboken, NJ, USA: John Wiley \& Sons, Inc.

Sunstein, C. (2001). Republic. Com. Princeton, NJ: Princeton University Press.

Tandoc E., Ling R., Westlund O., Duffy A., Goh D. and Wei L. (2017) Audiences' acts of authentication in the age of fake news: a conceptual framework. New Media and Society New Media \& Society 20(8), 27452763.

The Economist. (2018). The global slump in press freedom, (2018 July 23), available at https://www.economist. com/graphic-detail/2018/07/23/the-global-slump-inpress-freedom.

Thomassen J., Andeweg. R., \& Van Ham, C. (2017). Political Trust and the Decline of Legitimacy Debate: A Theoretical and Empirical Investigation into their Interrelationship. In S. Zmerli \&T. Van der Meer (Eds.) Handbook on Political Trust (pp. 509-525). Cheltenham: Edward Elgar Publishing.

Turper, S., \& Aarts, K. (2017). Political Trust and Sophistication: Taking Measurement Seriously. Social Indicator Research, 130(1), 415-434.

Van Aelst, P. (2017). Media Malaise and the Decline of Legitimacy: Any Room for Good News?. In C. Van Ham, J. Thomassen, K. Aarts, \& R. Andeweg (Eds.), Myth and Reality of the Legitimacy Crisis: Explaining Trends and Cross National Differences In Established Democracies (pp.105-114). Oxford: Oxford University Press.

Van der Meer, T.W.G., \& Hakhverdian, A. (2017). Political trust as the evaluation of process: A cross-nation- 
al study of 42 European countries. Political Studies, 65(1), 81-102.

Van Ham, C., \& Thomassen, J. (2017). The Myth of Legitimacy Decline: An Empirical Evaluation of Trends in Political Support in Established Democracies, in C. van Ham, J. Thomassen, K. Aarts and R. Andeweg (eds), Myth and Reality of the Legitimacy Crisis: Explaining Trends and Cross-National Differences in Established Democracies [Chapter 2] Oxford University Press.

Viner, K. (2016). How technology disrupted the truth. The Guardian, (12 July 2016), available: https://www. theguardian.com/media/2016/jul/12/howtechnologydisrupted-the-truth (2018-04-27).

Waisbord, S. (2000). Watchdog Journalism in South America: News, Accountability, and Democracy. Columbia University Press.

Xenos, M. and Moy, P. (2007). Direct and Differential Effects of the Internet on Political and Civic Engagement. Journal of Communication, 57(4), 704-718.

You, Y, and Wang, Z. (2019). The Internet, political trust, and regime types: a cross national and multilevel analysis. Japanese Journal of Political Science, 1-22 doi:10.1017/S1468109919000203

Zajonc, R.B. (2001) Mere exposure: A gateway to the subliminal. Current Directions in Psychological Science, 10(6): 224-228.

Zmerli, S., Newton, K., and Schmitt-Beck R. (2015) Mass media and political trust in Europe: testin for 'rainnmaker' effects in T. Poguntke, S. Rossteutscher, R. Schmitt-Beck and S. Zmerli (eds.) Citizenship and democracy in an era of crisis (pp. 75-92). London: Routledge. 